\title{
Detection of Viral Hemorrhagic Septicemia Virus
}

Viral hemorrhagic septicemia virus (VHSV) is considered to be one of the most important viral pathogens of finfish and is listed as reportable by many nations and international organizations (Office International des Epizooties 2006). Prior to 1988, VHSV was thought to be limited to Europe (Wolf 1988; Smail 1999). Subsequently, it was shown that the virus is endemic among many marine and anadromous fish species in both the Pacific and Atlantic Oceans (Meyers and Winton 1995; Skall et al. 2005). Genetic analysis reveals that isolates of VHSV can be divided into four genotypes that generally correlate with geographic location with the North American isolates generally falling into VHSV Genotype IV (Snow et al. 2004). In 2005-2006, reports from the Great Lakes region indicated that wild fish had experienced disease or, in some cases, very large die-offs from VHSV (Elsayed et al. 2006, Lumsden et al. 2007). The new strain from the Great Lakes, now identified as VHSV Genotype IVb, appears most closely related to isolates of VHSV from mortalities that occurred during 2000-2004 in rivers and near-shore areas of New Brunswick and Nova Scotia, Canada (Gagne et al. 2007). The type IVb isolate found in the Great Lakes region is the only strain outside of Europe that has been associated with significant mortality in freshwater species.

\section{muskellunge}

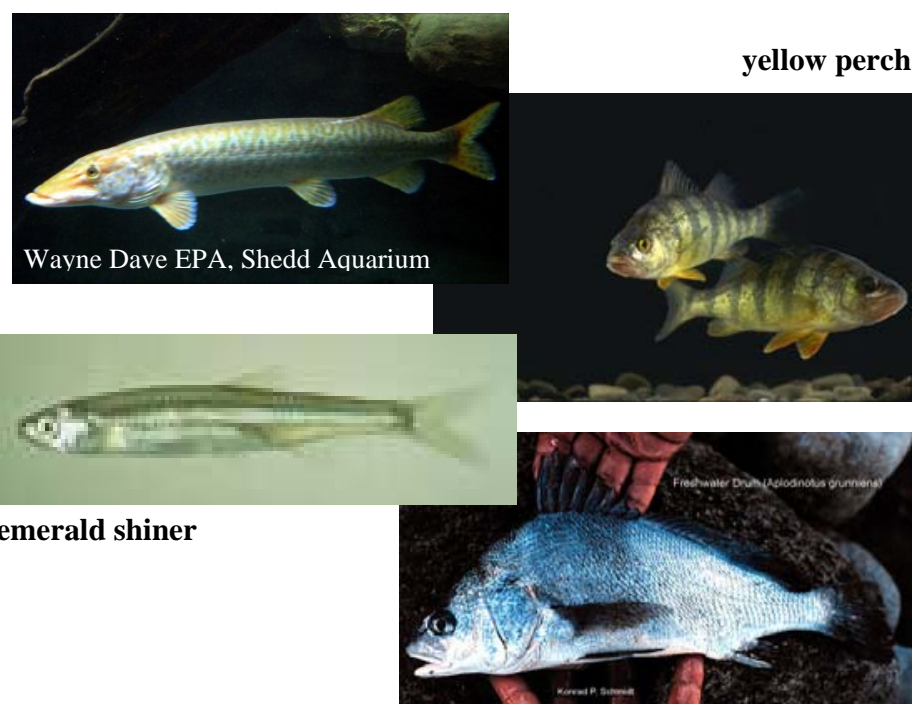

freshwater drum

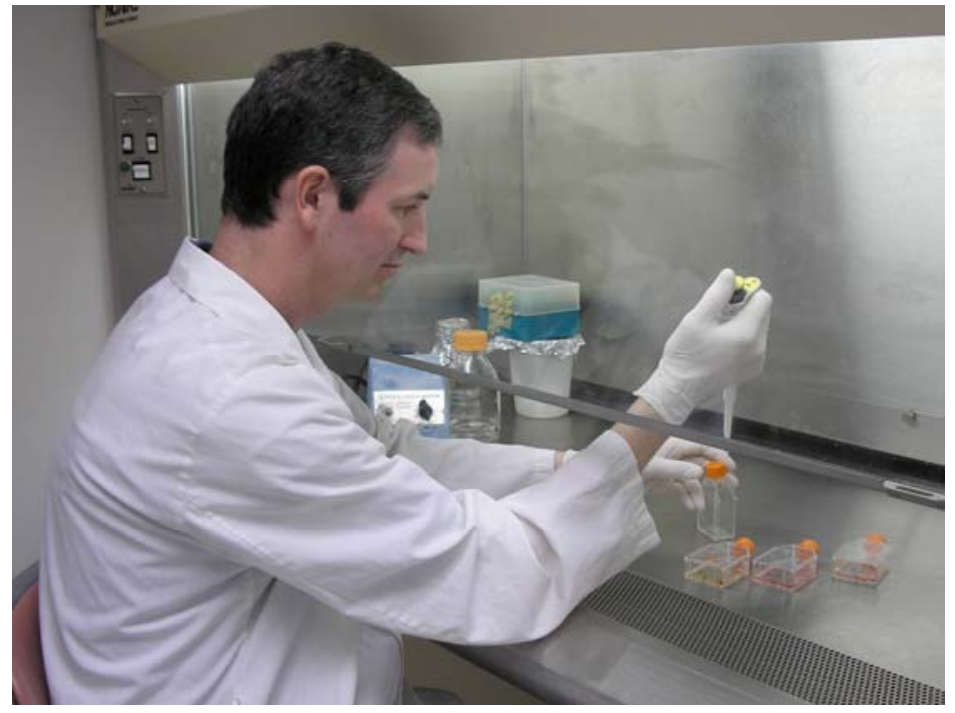

Cell culture and molecular assays are used for the detection and identification of fish viruses.

As of mid-2007, VHSV strain IVb has been isolated from fish in Lake Michigan, Lake Huron, Lake St. Clair, Lake Erie, Lake Ontario, the Saint Lawrence River, inland lakes in New York, Michigan and Wisconsin as well as the coastal areas of eastern Canada. The new strain has an exceptionally broad host range and has been isolated from over 25 species of finfish to date. Significant mortality has been reported in muskellunge, freshwater drum, yellow perch, round goby, emerald shiners and gizzard shad.

Fisheries managers throughout the US and Canada are concerned about the further spread of this highly virulent virus among populations of native freshwater fish and the introduction of VHSV into the private aquaculture industry could lead to trade restrictions as well as direct losses from disease. As a result, agencies in the US and Canada have placed restrictions on the movement of fish or fish products that could represent a risk for the spread of VHSV to regions outside of the currently known geographic range. These restrictions include requirements for viral examinations by standard methods. The purpose of this information sheet is to review some important factors for the isolation of VHSV Genotype IVb using cell culture assays and its identification by the polymerase chain reaction (PCR) assay. 


\section{Cell culture for initial isolation:}

Both the Manual of Diagnostic Tests for Aquatic Animals (OIE 2006) and the Suggested Procedures for the Detection and Identification of Certain Finfish and Shellfish Pathogens (American Fisheries Society 2005 - in revision) specify cell culture assays for determination of virus-free status. While European strains of VHSV grow well on the cell lines recommended by the OIE (e.g. RTG-2 and BF-2), isolates of the North American genotype are more efficiently isolated using the EPC, FHM or BF-2 lines (Table 1). These latter cell lines, available from the American Type Culture Collection, are acceptable to the OIE and specified in the revised version of the AFS "Bluebook".

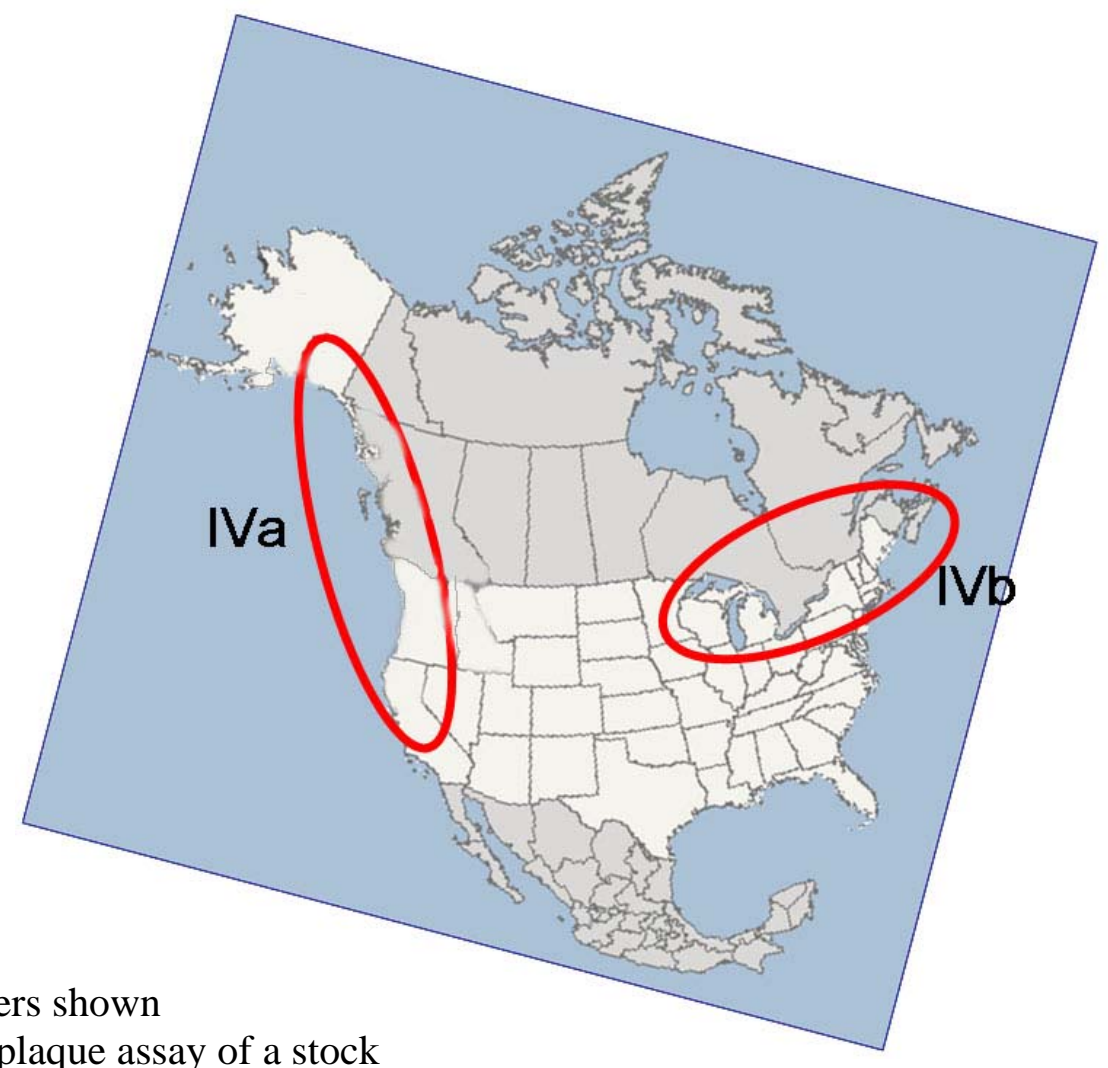

Table 1. Relative plating efficiency for various isolates of VHSV on selected cell lines. The numbers shown represent the $\log _{10}$ of the virus titer determined by plaque assay of a stock suspension of each virus isolate on each of the lines. The VHSV strains are: F1 (Denmark); 23-75 (France); KRRV (Japan); Makah (WA), muskellunge (MI) and mummichog (NB). The genotype of each isolate is shown in parentheses. n.d. = not done.

\begin{tabular}{|l|c|c|c|c|c|c|}
\hline & $\begin{array}{c}\text { F1 } \\
\text { (Ia) }\end{array}$ & $\begin{array}{c}\mathbf{2 3 - 7 5} \\
\text { (Ia) }\end{array}$ & $\begin{array}{c}\text { KRRV } \\
\text { (IVa) }\end{array}$ & $\begin{array}{c}\text { Makah } \\
\text { (IVa) }\end{array}$ & $\begin{array}{c}\text { muskellunge } \\
\text { (IVb) }\end{array}$ & $\begin{array}{c}\text { mummichog } \\
\text { (IVb) }\end{array}$ \\
\hline EPC-ATCC & 6.5 & 6.8 & 5.6 & 8.6 & 7.3 & 7.0 \\
EPC-Newport & 6.3 & 7.0 & 5.2 & 8.6 & 7.5 & 7.3 \\
FHM-J & 6.3 & 6.9 & 5.4 & 8.5 & 7.4 & 7.4 \\
FHM-Lamar & 6.5 & n.d. & 5.5 & 8.7 & 7.5 & 7.2 \\
CHSE-214 & 7.0 & 5.4 & 5.1 & 8.1 & 5.5 & 6.2 \\
RTG-2 & 7.2 & n.d. & $<3.7$ & 5.1 & 3.3 & 3.7 \\
BF-2 & 7.9 & 6.7 & 7.4 & 8.3 & 7.4 & 7.0 \\
\hline
\end{tabular}

Incubation temperature affects the growth of all fish viruses and strains of VHSV are best isolated at incubation temperatures between $15-18^{\circ} \mathrm{C}$ as recommended by the Manual of Diagnostic Tests for Aquatic Animals (OIE 2006) and the Suggested Procedures for the Detection and Identification of Certain Finfish and Shellfish Pathogens (American Fisheries Society 2005). As shown in Table 2, the Genotype IVb isolate of VHSV from the Great Lakes grew best at $15^{\circ} \mathrm{C}$. Plating efficiency began to decline at $20^{\circ} \mathrm{C}$, and the isolate did not grow at $25^{\circ} \mathrm{C}$.
Table 2. Plaque assay titers for a North American Genotype IVb isolate of VHSV from muskellunge plated on three cell lines and incubated at selected temperatures. The numbers shown represent the $\log _{10}$ of the virus titer detected by each of the lines.

\begin{tabular}{lllll} 
Cells & $10^{\circ} \mathrm{C}$ & $15^{\circ} \mathrm{C}$ & $20^{\circ} \mathrm{C}$ & $25^{\circ} \mathrm{C}$ \\
\hline EPC-ATCC & 7.04 & 7.06 & 6.26 & $<3.40$ \\
BF-2 & 6.85 & 7.22 & 6.98 & $<3.40$ \\
FHM-J & 7.00 & 7.34 & 6.99 & $<3.40$
\end{tabular}


More so than for other fish viruses, the $\mathrm{pH}$ of the cell culture medium is particularly important for the successful isolation of VHSV. Table 3 shows the effect of selected $\mathrm{pH}$ levels on the ability of three cell lines to detect the Genotype IVb isolate of VHSV from the Great Lakes. It is obvious from the data that the $\mathrm{pH}$ of the culture medium should remain at or above $\mathrm{pH} 7.4$ during the assay.

\section{Polymerase chain reaction for confirmation:}

The polymerase chain reaction assay has largely replaced the serum neutralization assay as a confirmatory test for VHSV. For the PCR assay to be broadly useful, it is important that the primers be located in regions of the virus genome that are conserved among all the strains of the virus that might be encountered. Following discovery of the Great Lakes strain of VHSV, sequence analysis of the new isolates showed that the primers recommended by the American Fisheries Society Fish Health Section Bluebook for PCR identification of VHSV were not optimal. The revised version of the VHS section of the Bluebook (available at no charge on-line at http://web.fisheries.org/units/fhs/VHS_inspection. html) contains new PCR primer sequences that are identical to those currently specified by the OIE Manual of Diagnostic Tests for Aquatic Animals. In addition, the revised VHS section of the Bluebook now recommends use of an extraction procedure for preparation of viral RNA from cell culture fluids rather than a simple heat treatment. These changes have resulted in the VHS sections of the Bluebook and OIE Manual becoming essentially equivalent.

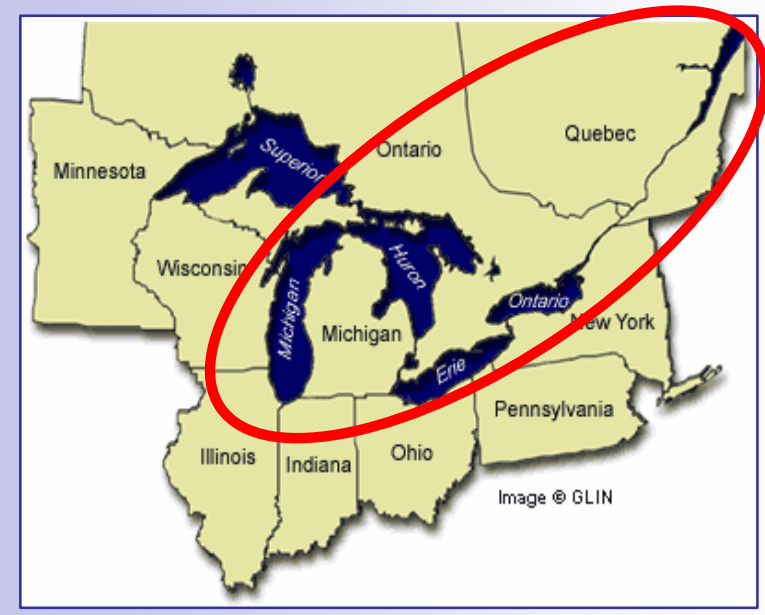

Sites of VHSV IVb isolation in the Great Lakes as of summer 2007.
Table 3. Plaque assay titers for a North American Genotype IVb isolate of VHSV from muskellunge plated on three cell lines and incubated at selected $\mathrm{pH}$ levels. The numbers shown represent the $\log _{10}$ of the virus titer detected by each of the lines.

\begin{tabular}{lccccc} 
Cells & pH 6.6 & pH 7.0 & pH 7.4 & pH 7.8 & pH 8.2 \\
\hline EPC-ATCC & $<3.40$ & 3.40 & 7.04 & 7.13 & 6.94 \\
BF-2 & $<3.40$ & $<3.40$ & 7.26 & 6.92 & 7.15 \\
FHM-J & $<3.40$ & $<3.40$ & 7.25 & 7.25 & 7.38
\end{tabular}

\section{VHSV Disease Outbreaks in North America}

West Coast: VHSV genotype IVa causes significant mortality in wild marine forage fish such as herring and sardines. These fish are critical to Pacific ecosystems.
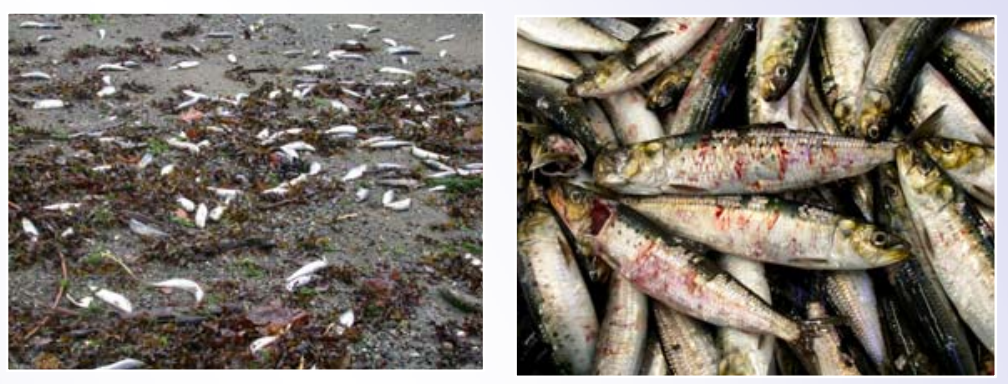

Photos courtesy of Garth Traxler.

Great Lakes: As of mid-2007, VHSV strain IVb has been isolated from fish in Lake Michigan, Lake Huron, Lake St. Clair, Lake Erie, Lake Ontario, the Saint Lawrence River, inland lakes in New York, Michigan andWisconsin as well as the coastal areas of eastern Canada. Significant mortality has been reported in muskellunge, freshwater drum, goby, burbot, yellow perch, gizzard shad, and smallmouth bass. It has been isolated from several other species including chinook salmon.
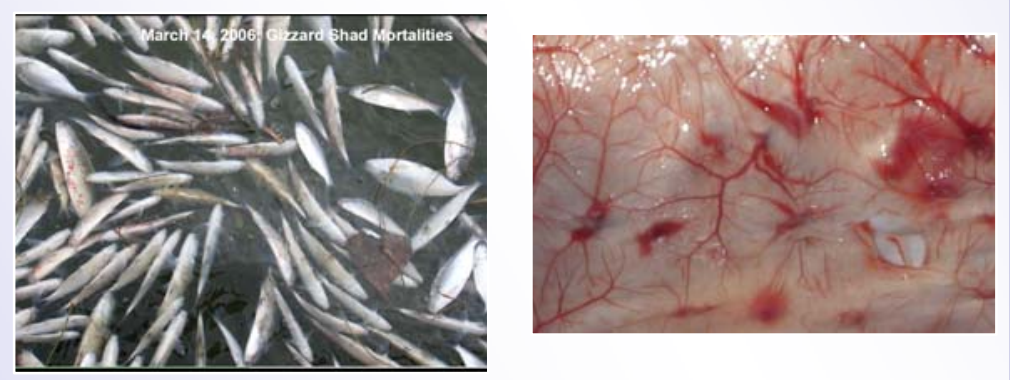

Hemorrhagic disease in gizzard shad. Photos courtesy of Mohammed Faisal.
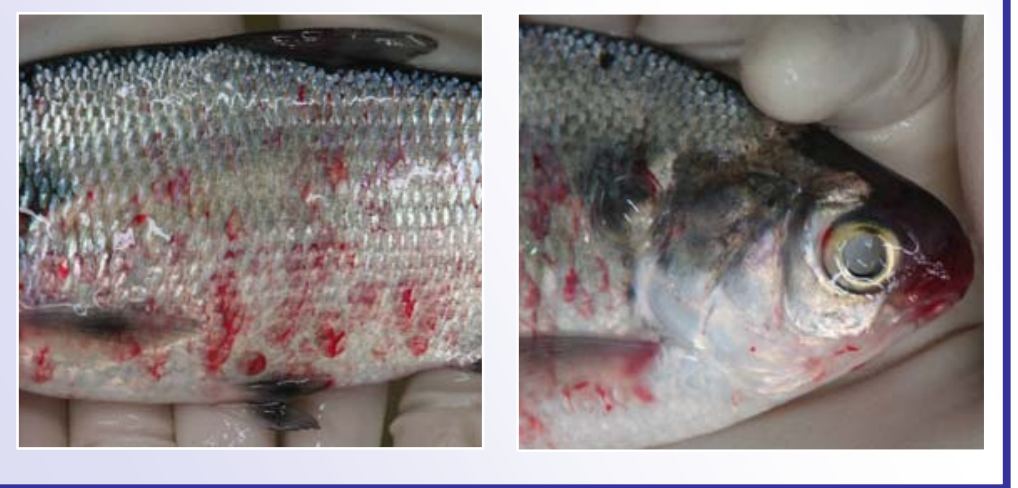


\section{References:}

American Fisheries Society. 2005. Suggested Procedures for the Detection and Identification of Certain Finfish and Shellfish Pathogens. American Fisheries Society, Bethesda, MD. This publication is currently in revision. For the new section on VHSV go to: http://web.fisheries.org/units/fhs/ VHS_inspection.html

Elsayed, E., M. Faisal, M. Thomas, G. Whelan, W. Batts and J. Winton. 2006. Isolation of viral hemorrhagic septicemia virus from muskellunge, Esox masquinongy (Mitchill), in Lake St. Clair, Michigan, USA reveals a new sub-lineage of the North American genotype. Journal of Fish Diseases 29:611-619.

Gagné, N., A.-M. MacKinnon, L. Boston, B. Souter, M. Cook-Versloot, S. Griffiths, and G. Olivier. 2007. Isolation of viral haemorrhagic septicaemia virus from mummichog, stickleback, striped bass and brown trout in eastern Canada. Journal of Fish Diseases 30:213-223.

Lumsden, J. S., B. Morrison, C. Yason, S. Russell, K. Young, A. Yazdanpanah, P. Huber, L. AlHussinee, D. Stone and K. Way. 2007. Mortality event in freshwater drum Aplodinotus grunniens from Lake Ontario, Canada, associated with viral haemorrhagic septicemia virus, Type IV. Diseases of Aquatic Organisms 76:99-111.

Meyers, T.R. and J.R. Winton. 1995. Viral hemorrhagic septicemia virus in North America. Annual Review of Fish Diseases 5:3-24.

Office International des Epizooties. 2006. Manual of Diagnostic Tests for Aquatic Animals (5th Edition). Office International des Epizooties, Paris.

Skall, H. F., N. J. Olesen, and S. Mellergaard. 2005. Viral hemorrhagic septicaemia virus in marine fish and its implications for fish farming a review. Journal of Fish Diseases 28:509-529.

Smail, D. A. 1999. Viral haemorrhagic septicaemia. Pages 123-147 in P. T. K. Woo, and D. W. Bruno, editors. Fish Diseases and Disorders, Volume 3: Viral, Bacterial and Fungal Infections. CAB International, New York, New York.
Snow, M., N. Bain, J. Black, V. Taupin, C. O. Cunningham, J. A. King, H. F. Skall, and R. S. Raynard. 2004. Genetic population structure of marine viral haemorrhagic septicaemia virus (VHSV). Diseases of Aquatic Organisms 61:11-21.

Winton, J. R., and K. Einer-Jensen. 2002. Molecular diagnosis of infectious hematopoietic necrosis and viral hemorrhagic septicemia. Pages 49-79 in C. Cunningham, editor. Molecular Diagnosis of Salmonid Diseases. Kluwer, Dordrecht.

Wolf, K. 1988. Viral hemorrhagic septicemia. Pages 217-248 in Fish Viruses and Fish Viral Diseases. Cornell University Press, Ithaca, NY.

Infectious disease is increasingly recognized as an important feature of aquatic ecosystems; however, the impact of disease on populations of wild fish has been difficult to study. While many of the viral, bacterial, protozoan and fungal pathogens of fish that were initially discovered in captive animals are actually endemic among wild populations, the introduction of exotic pathogens into aquatic systems can lead to explosive mortality and may be especially threatening to native stocks. At the WFRC, field and laboratory investigations, aided by the tools of molecular biology, have begun to provide information on the ecology of infectious diseases affecting natural populations of fish in freshwater and marine ecosystems.

Further Reading:

A complete list of WFRC publications may be found at: http://wfrc.usgs.gov/pubs/pubs.htm
For additional information, please contact:

James Winton, Gael Kurath or William Batts U.S. Geological Survey Western Fisheries Research Center 6505 NE $65^{\text {th }}$ Street, Seattle, WA 98115

Phone: 206-526-6282; FAX 206-526-6654

E-mail: jim_winton@usgs.gov; gael_kurath@usgs.gov; bill_batts@usgs.gov 